\title{
University teachers' attitudes towards English language curriculum of M.Ed. semester system
}

\author{
Pitamber Paudel \\ Tribhuvan University, Nepal
}

\begin{abstract}
A curriculum changes as per the concurrent philosophical and methodological changes of a country. This study investigates the Tribhuvan University (TU) teachers' attitudes towards the current Masters level English language (semester system) curriculum. In order to achieve this goal, explanatory sequential mixed research design was employed. Forty-five English language teachers from both constituent and affiliated campuses of Tribhuvan University, Nepal, were purposively selected. The research shows that the university English teachers had positive attitude towards the current curriculum for its input and process. However, they did not like the context of its design and the implementation process. This implies that the policy maker and curriculum designers should make an analysis of the context in terms of situation and the needs of the stakeholders before selecting the courses and their contents so that the curriculum can be effectively implemented.
\end{abstract}

Keywords: context,English language curriculum, input, involvement, process

\section{Introduction}

Modern methods have been blamed to be superficial, imposed and a prescription of readymade curriculum rather than a creation and contextualization of knowledge. Rodgers (2010) calls them dishonest ELT and argues that top down syllabuses, which are prepared by experts, are distorted and delivered to learners by language teachers, keep learners very passive recipients leading to cultural imposition, and prevent learners from more learning.
The top down approach-based curricula exert external agendas on learners without regarding their interest and choices.

To overcome the inherent limitations of modern ELT curriculum, postmodern English language curricula have been designed and implemented. Fahim and Pishghadam (2009) argue that post modernists are essentially constructivists, who reject the global discussion and theories, question the notion of expertise, and focus on local context and need. 
Kumaravadivelu (2006) discusses about the principle of practicality, possibility and particularity which the postmodern language curricula should maintain in their courses. Similarly, Akbari (2008) argues that postmodern practitioners can solve the problems of political ideologies, problem of injustice, marginalization and representation, voice and inclusion, effective design, and delivery of language curricula, materials and resources. In the same backdrop, Ahmadian and Rad (2014) concede that post-method pedagogy favours a globalized learner cantered curriculum.

Regarding the global methodological and philosophical changes in English language teaching and learning, Tribhuvan University, Nepal has also restructured and revamped its curricula at Master level with the aim of meeting local and global needs of the present generation without, at the same time, compromising the needs and interests of the future generations. TU practised semester system after National Education System Plan (2028-2034 B.S.) in its Proficiency, Bachelor and Master levels. However, due to several obstacles and changing political scenario, semester system was replaced by an annual system in 2038 B.S.,although agriculture, engineering, medical, forestry, BBA, MBA programmes continued to conduct the semester basis (Bista, 2016). The need of a semester system was felt again due to some drawbacks in the annual system like; improper management of educational calendar, teaching process and result, uncontrolled student admission, irregularity of the students, exam oriented teaching and learning, time gap between students admission year, teaching learning year and passed year and so on (Bista, 2016). Considering all these facts, Tribhuvan University has implemented semester system in Masters' level first in the central campus in 2014, then in the campuses of Kathmandu valley and, subsequently in 2017 all over the country in all subjects, faculties and institutions in its constituent and affiliated colleges.

Since teachers are the real practitioners of the curriculum, their input and involvement play a significant role in an effective implementation and in achieving expected outcomes of the curriculum. It is necessary to examine how teachers perceive the curriculum and their roles in designing and implementing processes of it. In this context, this article explores the teachers' attitudes towards English language curriculum of M.Ed. semester system. By doing so, I am drawing an implication for the policy makers, curriculum designers and the administrators to address the teachers' voice for effective designing and implementation of ELT curriculum.

\section{Review of literature}

Curriculum is an overall plan of an educational programme which incorporates the context, goals, content, process, resources and the output of the programme. Egan (2003) noted that the term curriculum has its origin in the running/chariot tracks of Greek (literally meaning a course) and in Latin; curriculum is a racing chariot where the word currere means to run. Mednick (2006) in this context asserted that curriculum is about all the learning 
activities that are carefully planned and guided by the education institution involved and carried out by learners in groups or individually in class or off class contexts. For Breen (2001), curriculum is a broader concept in which different elements of a teaching procedure like aims, content, methodology and evaluation are addressed.

In the words of Null (2011), it is about defining and proposing the courses to be taken by students of a particular academic programme. These accounts reveal that a curriculum is a roadmap of an educational programme which incorporates the goals and objectives, content, instructional and evaluation process and the output of the programme. In this sense, it is a blueprint of a programme that makes decision about the various resources as per the needs and background of the learners and teachers. Wiggings and McTighe (2006) enunciate curriculum as a map to achieve the outputs of the desired appropriate learning activities and assessment. For Uwadiae (2018) it is a chain of several activities which are needed to translate educational goals into concrete activities, performance, materials and more specifically, change in the behavior of the practitioners. Kubecki (2018) connects curriculum with an element of rebutting education while Simons (2019) believes curriculum to be beyond lesson plan and takes it as a map of achieving educational goals from classroom, institutional to national level.

The aforementioned literature affirm that curriculum is an orderly plan of the study of goals, content, implementation, evaluation and the context of the whole educational programme. It includes who, why, what, when, how and where aspects along with the experiences of all the concerned stakeholders and negotiation among them.

Regarding the language curriculum development process, Johnson (1989) presented curriculum planning, designing a syllabus, programme implementation and classroom implementation as the four stages of language curriculum development. Moreover, Brown (1995) presented need analysis, objectives, testing, materials, teaching and evaluation as the systematic procedures employed in developing a language curriculum. For Peacock (2009) evaluation is the starting point of curriculum development. Breen (2001) believed curriculum development as a cyclical process where evaluation of each interrelated and interwoven step is essential. Nation and Macalister (2010) asserted that language curriculum design is a kind of writing activity which can be studied as a process rather than an end. They present an analysis of needs, environment, principles in format and presentation, content and sequencing, monitoring and assessing and evaluation, the aims of which is to judge if the curriculum is appropriate, adequate, effective and efficient or it requires modification or radical change.

Evaluations of the curriculum help teachers promote their professionalism and enhance quality and standard of the institution. The involvement of teachers in curriculum design, evaluation and redesign on the basis of feedback develop the feeling of ownership in the curriculum though it is a challenging job. Moreover, it can provide feedback to 
policy makers, curriculum designers to design and develop appropriate curriculum both in global and local contexts. Brown (1989) suggested a fourpoint model for language programme evaluation which includes product oriented approach, static characteristic approach, process oriented approach and decision facilitation approach. Likewise, Scriven (1972) introduced a goal free model in which evaluators aim to find out the actual outcomes of a programme without taking any reference of the goals that the programme developers stated while developing the programme. Moreover, Stufflebeam (2003) introduced context, input, process and product model for evaluating curriculum. Context includes needs, opportunities, scene and setting, problems, issues and challenges, input, incorporates content, course objectives, infrastructures and resources, process involves teaching-learning activities, instructional techniques and evaluation activities and product incorporates skills, social position and values.

Higher Education has become the basic need in the $21^{\text {st }}$ century, which produces high quality human resources for developing the nation. Ramley (2014b) in this backdrop insisted that to deal with the $21^{\text {st }}$ century's rapid industrialized world market, higher education institutions are in great pressure of producing skilled and knowledgeable work force. Traditionally, higher education institutions were confined to educate students for lives of public service and to advance knowledge through research but today as Spelling Commission (2006) identifies they are required to prepare graduates with knowledge, skills, ethical responsibility, and performance to fulfil the demands of present generation. In the same context, Selingo (2016) conceded that the higher education institutions are in the pressure of promoting college access, affordability and completion in today's uncertain future in one hand, and on the other hand, they have to enhance the students' competencies and abilities to think critically, logically and rationally to be able to sustain in global communities.

\section{The research context}

Eleven universities and five institutions are serving higher education in different fields and subjects where TU has been offering bachelor to $\mathrm{Ph}$. D. level educational programmes in different subjects (Bhattarai, 2014; Paudyal, 2016). With the aim of generating innovative and globally contemporary appropriate human resource, TU changed its annual Master level programme into the semester system in 2014, first in the central department, then extended it into all constituent and affiliated campuses of the Kathmandu valley and then all over the country in 2017.

The semester system in educational programme is regarded as processbased, and student-centered teachinglearning system in which study is based on credit hours and result is carried out in time. English language curriculum (2015) makes the provision of internal evaluation (40\%) and external evaluation $(60 \%)$ in each course offered in first to fourth semesters. A course is given 3 credit hours and scoring is on the GPA (Grade Point Scale) where 80\% attendance of the students is mandatory to appear the external examination 
(FOE, n.d.). This indicates that irregular students cannot be enrolled in this programme.

The English language curriculum consists of four courses in the first semester (phonetics and phonology (Eng. Ed. 515), English usage and use (Eng. Ed. 516), interdisciplinary readings (Eng. Ed. 517) and second language acquisition (SLA) theories and research (Eng. Ed. 518). Similarly, it has, in its second semester, linguistics in application (Eng. Ed. 525), language society and power (Eng. Ed. 526), critical discourse analysis (CDA) (Eng. Ed. 527), and readings in English part-1(Eng. Ed. 528). In the third semester, it includes English language teaching (ELT) pedagogy and materials (Eng. Ed. 536), dimensions of teacher development (Eng. Ed. 537) and ESL research and testing (Eng. Ed. 538). Finally, it has English language teaching curriculum and syllabus (Eng. Ed. 546), Translation studies (Eng. Ed. 547), Academic writing (Eng. Ed. 548), and ELT seminar and report writing (Eng. Ed. 549) in the fourth semester (as cited from FOE, n.d.). All the courses offered in $4^{\text {th }}$ semester are elective and apart from these core English courses, students have to complete teaching practice, thesis writing and some other educational courses.

There is a dearth of research on English language curriculum in Nepal, Therefore, empirical data on their effectiveness cannot be definitively presented. However, research on teachers' involvement in other contexts have produced mixed findings. Carl (2005), for example, investigated teachers' viewpoints about their involvement in curriculum change process in South Africa and revealed that teachers only took part in the implementation stage of curriculum development. Chongbang's (2014) study showed that the pass percentage of the students is higher in semester system than in annual system specifically in three educational courses. Similarly, Bista (2016) studied teachers' attitude towards mathematic curriculum implemented in Tribhuvan University, Nepal and showed their positive attitude on it.

The present study examines the English language curriculum offered in Masters of education under Tribhuvan University, Nepal from teachers' perspectives focusing in the context, input, process, teachers' involvement and strengths and weaknesses of the curriculum. The study is based on the theoretical framework of context, input, process and product evaluation model introduced by Stufflebeam (2003) (discussed in preceding part). Furthermore, it discusses strengths and weaknesses of teachers' involvement the curriculum process.

\section{Methodology}

The theoretical standpoint in this study was informed by the pragmatist paradigm which aims to understand individuals' insights of the phenomenon which they have been working within their respective contexts. In this regard, knowledge is regarded as personal, subjective and unique (Cohen, Manion \& Morrison, 2009) and therefore, the responses collected through close and open ended questions were validated with the information collected through interview. The research design employed 
UNELTA

in the study was explanatory sequential which consists of two phases; quantitative followed by qualitative (Terrel, 2012). In this study, equal priority is given to both phases and the data are integrated during interpretation. The explanatory sequential mixed research design(Terrel, 2012) was employed in this research as shown in Figure 1.
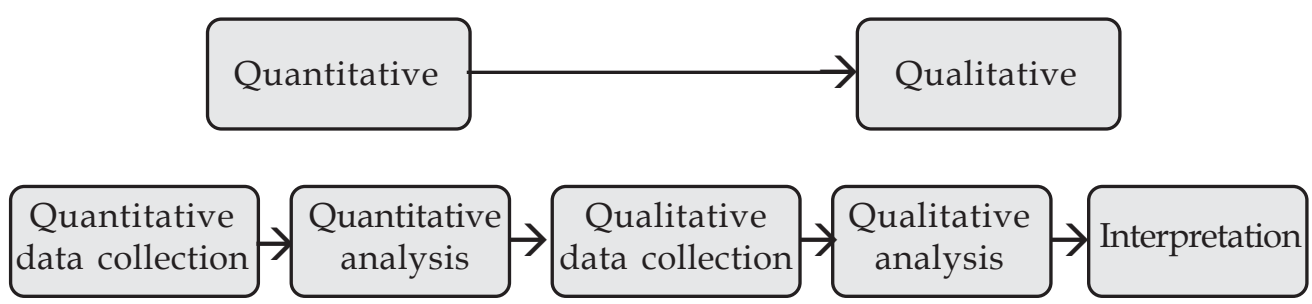

Figure 1; Explanatory Sequential Mixed research Design (Terrel, 2012)

60 teachers from 30 different campuses (both constituent and affiliated) under TUwere selected purposively. The teachers were sent closed and open ended questionnaires through e-mail maintaining proper time gap, that is, after receiving the responses on closed ended questions, open ended questions were sent. In each category of the closed questions, one column of remarks was given where they were asked to add some more information if they wished. I received the responses on both questionnaires only from 45 teachers. Thus, the actual sample of the study was 45 teachers teaching English language courses in Masters of education for quantitative data. After receiving and analysing the quantitative data, 10 teachers from different campuses were interviewed for qualitative data virtually as well as face to face as per their convenience. The collected information was transcribed, coded in graphological form. Then, both quantitative and qualitative data were integrated, analysed and interpreted numerically as well as textually under 5 themes.

\section{Results and discussion}

Since this study aims to explore teachers' perception on the implemented English language curriculum at the semester system in the Master of Education, 
innovative, contextual, need-based and relevant. Table 1 presents the teachers' attitudes towards context of implemented curriculum.

\section{Table 1}

Teachers' Attitudes towards Context of the Curriculum

\begin{tabular}{|l|c|c|c|l|}
\hline Context indicators & Agree & Disagree & Not sure & \multicolumn{1}{c|}{ Remarks } \\
\hline Need based & 31 & - & 7 & Actual need is not found \\
\hline Contextuality & 31 & 12 & 2 & \\
\hline Creates opportunities & 31 & 7 & 7 & $\begin{array}{l}\text { Doubt if it prepares globally } \\
\text { and locally competent } \\
\text { manpower } \\
\text { Poor Scene and setting }\end{array}$ \\
\hline
\end{tabular}

\begin{tabular}{|l|l|c|c|c|c|c|} 
Challenges $\rightarrow$ & $\begin{array}{c}\text { Course- } \\
\text { completion } \\
\text { (Length) }\end{array}$ & $\begin{array}{c}\text { Students } \\
\text { poor } \\
\text { background }\end{array}$ & $\begin{array}{c}\text { Traditional } \\
\text { Classroom } \\
\text { setting }\end{array}$ & $\begin{array}{c}\text { Lack of } \\
\text { Students' } \\
\text { seriousness/ }\end{array}$ & $\begin{array}{c}\text { Lack of } \\
\text { Training } \\
\text { to the } \\
\text { teachers }\end{array}$ & $\begin{array}{c}\text { Poor } \\
\text { administ- } \\
\text { rative }\end{array}$ \\
\hline $\begin{array}{l}\text { No. of } \\
\text { respondents }\end{array}$ & 35 & 2 & 40 & 3 & 3 & 40 \\
\hline Remarks & $\begin{array}{l}\text { So many } \\
\text { content } \\
\text { but less } \\
\text { time. }\end{array}$ & $\begin{array}{l}\text { Disagre- } \\
\text { ement in } \\
\text { power } \\
\text { point. } \\
\text { (Ss) }\end{array}$ & $\begin{array}{l}\text { No } \\
\text { training } \\
\text { for } \\
\text { teachers }\end{array}$ & \\
\hline
\end{tabular}

Table 1 reveals that 31 participants out of 45 claimed that the courses were needbased and useful for the learners. In the same issue, seven of the participants were not sure if the courses make the learners competent in global market. Similarly, 26 participants agreed that the courses were contextual, however five of them disagreed that it was appropriate to the context. Twelve of the participants disagreed with the usefulness of the curriculum and two were unsure of it. Seven of the participants did not mention their view on the issue 'need-based', usefulness and contextualization of the curriculum. All the participants reported that the university setting was not satisfactory 
and not different from that of the annual system. For example, T1, during an interview, stated, "The courses are designed and taught without carrying out any research to find out the actual needs of the prospective teachers and students, therefore, it is hard to say whether they meet the needs of the local and global contexts". In the same context, another informant $\mathrm{T} 2$ added:

\section{I think the curriculum is need based though the process of developing did not involve the concerned people in that process and developed without analysing the needs. The goals are sound enough to meet the changing perspectives of language teaching. The situation is not almost favourable because it has been implemented without developing well infrastructure and preparation.}

These accounts above reveal that the English language curriculum at semester system is more need oriented than that of annual system. Determining the needs that are to be addressed by a programme helps in determining objectives and the content to be incorporated (Worthen, Sanders \& Fitzpatrick, 1998). Addressing the needs supports the curriculum to be practicable, effective and relevant. The data further revealed that the situations for implementing curriculum do not support the goals of curriculum, that is, the curriculum designer made curriculum implementation process quite complicated and difficult as a curriculum was largely affected by physical, social, cultural and political situations where ELT curricula/syllabi were implemented (MacKey \& Gass,
2005). The participants saw that the English curriculum had opened the opportunities of interdisciplinary knowledge and jobs. However, they did not believe that it made them competent both in local and global markets. As for the challenges, 35 participants reported that completing the course on time was the main challenge. The responsible factors were poor background of the students, traditional classroom setting and poor administrative mechanism. Moreover, three participants suggested that the lack of seriousness on the part of students, lack of orientation and training for teachers and lack of workshop and conferences for the students were some other challenges.

Some of the challenges I have been facing as a teacher are; lack of supportive resources; traditional classroom setting that hinders group mode of teaching and learning, poor administrative mechanism, lack of seriousness on the part of students and designing of the curricula without consultations and adequate resources making it difficult to implement the curriculum as it intends (T5).

The accounts above reflect on the inadequate preparedness for the implementation of the course which makes it difficult to achieve its goals. The participants were not happy with the administrators, policy makers and curriculum designers in the sense that the curricula were designed and implemented without preparing the teachers for it and without improving the physical infrastructures of the classroom. Moreover, the lengthy courses and the 
students' disagreement in powerpoint presentation added extra load to the teachers. Teachers were expecting training, workshops and their ideas to be incorporated in the curricula for making them more relevant, need based and suitable in the global market and urge the policy makers and administrators to improve the contexts where curriculum was implemented.

\section{Perception of input of the curriculum}

Regarding the course objectives and contents, Table 2 shows teachers' anticipation towards input of the curriculum.

\section{Table 2:}

Teachers' Perception of input of the curriculum

\begin{tabular}{|l|c|c|c|c|l|}
\hline $\begin{array}{l}\text { Input } \\
\text { indicators }\end{array}$ & Suitable & $\begin{array}{c}\text { Complex } \\
\text { and } \\
\text { repeated }\end{array}$ & $\begin{array}{c}\text { Need more } \\
\text { reading } \\
\text { materials }\end{array}$ & $\begin{array}{c}\text { Pradicably/ } \\
\text { usable }\end{array}$ & \multicolumn{1}{|c|}{ Remarks } \\
\hline Objectives & 40 & 1 & 40 & 41 & $\begin{array}{l}\text { Situation unsuitable for } \\
\text { effective } \\
\text { implémentation }\end{array}$ \\
\hline Contents & 40 & 1 & 40 & 41 & $\begin{array}{l}\text { Mismatch between } \\
\text { content and } \\
\text { infrastructures }\end{array}$ \\
\hline Resources & 45 & & & 45 & $\begin{array}{l}\text { Not available in the } \\
\text { market }\end{array}$ \\
\hline
\end{tabular}

Table 2 shows that 40 of the participants found the objectives and content of the courses were suitable and that they expected some additional reading courses and text on them. Some of the participants found the course to be very complex and repetitive, and doubted the practicality and usability of the courses because 'our infrastructure is very poor and the course designers seems to have designed the courses without considering our infrastructures' (T1).
The teachers wanted autonomy to adjust the curricula in their contexts by adding, omitting or modifying some aspects of the content incorporated on them. The data further revealed that the courses did not have sufficient reading and critical thinking developing materials which the teachers expect to have. Regarding the unavailability of resources. T8 said:

I think the resources that are recommended as prescribed and 
reference make each teacher search the books or article easy but the indication of the pages of book to cover the particular content limits the horizon of knowledge. I have had a bad experience that the books which were listed as resource material was not found when I reached to book stores and webpage and then I asked the curriculum designers, he/she also was unknown about the book.

The aforementioned discussion suggests that the curriculum was provided sufficient resources but the unavailability of the resources affected its implementation

\section{ELT curriculum process}

The content of the course determines its instructional techniques (teachinglearning activities) which can be context and policy specific. The English language teaching curriculum at Masters' level in semester system has provision of both summative and formative evaluation systems. For formative evaluation, 40 points are allocated and 60 points is for summative evaluation. The most commonly suggested instructional techniques in each course are lecture method, group work, pair work, project work, discussion, presentation, exploration, demonstration, assignments and self-study. Table 3 reveals the teachers conceptualizations in the processes of ELT curriculum.

\section{Table 3}

Teachers' conceptualization of Process in ELT Curriculum

\begin{tabular}{|l|c|c|c|c|}
\hline $\begin{array}{c}\text { Indicators of } \\
\text { Process }\end{array}$ & $\begin{array}{c}\text { Satisfa- } \\
\text { ctory }\end{array}$ & Conditional & $\begin{array}{c}\text { Not } \\
\text { effective }\end{array}$ & \multicolumn{1}{|c|}{ Remarks } \\
\hline Instructional Strategies & 35 & 7 & & $\begin{array}{l}\text { Implementation in } \\
\text { doubt }\end{array}$ \\
\hline Evaluation Process & 44 & 1 & & $\begin{array}{l}\text { Length of the } \\
\text { courseand centrally } \\
\text { controlled are } \\
\text { hinderances }\end{array}$ \\
\hline
\end{tabular}

In table 3, 35 teachers showed their satisfaction towards the suggested instructional techniques whereas seven teachers out of 45 mentioned that instructional techniques and their effectiveness were conditional and three teachers left it unanswered. In this connection, T2 claimed "As to instruction, the courses prioritize the combination of conventional methods such as lecture and new one such as project work, which is satisfactory." In the same vein, the next informant L6 responded that the instruction techniques were practical, relevant and suitable while L8 raised question in their implementation in our poorly structured and traditionally modelled classrooms. 
These accounts exhibit that theoretically prescribed instructional strategies in the curriculum are useful, standard and relevant but their applications are subject local conditions.

Similarly, 44 participants found that the shift from total summative to some sort of formative evaluation is a good aspect in the curriculum whereas one out of 45 did not see any progress in the evaluation system since the marks of formative evaluation is determined by the score that the learners' obtained in external evaluation. Explaining it further, T5 conceded, "Evaluation system is formative and progressive which can be used in an effective way to provide independent formative evaluation which should not be controlled by external evaluation since if the students internal marks and external marks get the differences of $20 \%$, the marks of internal evaluation is automatically decreased in the same ratio.

\section{Teacher involvement in the de- signing process}

Curriculum designing and implementation requires teachers' direct or indirect involvement for its effectiveness and success. Table 4 reflects teachers' participation in curriculum designing process.

\section{Table 4}

Teachers' involvement in curriculum development process

\begin{tabular}{|c|c|c|c|c|}
\hline $\begin{array}{c}\text { Nature } \Rightarrow \text { of } \\
\text { Involvement }\end{array}$ & $\begin{array}{c}\text { Actively } \\
\text { Engaged }\end{array}$ & $\begin{array}{c}\text { Consulted } \\
\text { but not } \\
\text { engaged }\end{array}$ & $\begin{array}{c}\text { Totally } \\
\text { being } \\
\text { Ignored }\end{array}$ & Remarks \\
\hline $\begin{array}{l}\text { No } \Rightarrow \text { of } \\
\text { participants }\end{array}$ & 7 & 5 & 33 & Still top down influence is heavy \\
\hline
\end{tabular}

feedback for the improvement of the students' study. However, the length of the course hinders this system as we have to rush to complete the course on time". In the same manner, the next participant expressed that producing formative evaluation is good but determining its score on the basis of external evaluation was to control the classroom autonomy, indirectly leads to annual system (T4).

These discourses affirm that the evaluation system is shifting in progressive manner however it is not effectively implemented. The data further confirms that there should be
Concerning the teachers' involvement in the curriculum design process, table 4 reflects that out of 45 , only seven participants claimed that they were actively engaged; they conducted discussion among the stakeholders, took the references of foreign universities' English language teaching curricula and finalized the curriculum. On the other hand, five participants reported that they were not involved in the designing process but they were consulted by the team of experts seeking their views and ideas, and 33 participants claimed that they did not have any opportunity to 
share their views on the nature of the courses and curriculum.

The analysis of the interview showed that the lack of information is a negative factor that influenced the practitioners' attitude towards the effective implementation of curriculum. This point was illustrated by one of the participants (T3) as "We did not have voice in the curriculum contents and courses. Nobody asked for our opinions. I do not think that anybody's opinions were taken into consideration. It was also a top down process as annual system".

\section{Strengths and weaknesses of the English language curriculum}

Participants' perception of the effectiveness of the implemented English language curriculum revealed some positive and negative aspects. The analysis of interview revealed that despite the weaknesses, curricular innovation attempts were, as T2 said, in the right direction:

It is possible to state that there are positive shift in the curriculum. We have had great improvements in the last ten years. The curriculum has been shifted from teacher to learner, theoretical to practical, summative evaluation to formative, non-culture to inter-culture, mono-disciplinary to interdisciplinary, lecture to discovery and project and rote to creative and innovative learning (T2).

T3 suggested that the literary and critical texts included in semester curriculum helped students enhance their creative and critical skills. Similarly, T7 emphasized the role of need analysis and states, "It is necessary to carry out a need analysis survey and the expected outcomes of the programme should be identified. Then, the courses and activities which are relevant and useful to achieve the expected outcomes should be selected and organized." The lack of teacher consultation in the curriculum development process makes it as O'Sullivan (2004) regards it, a top down model, which is ineffective and inefficient since it focuses only in input and output where actual processes are lacking.

According to the teachers interviewed, there was a total disregard teachers' voice in the curriculum evaluation process. They agreed that no feedback was received from the teachers and students about the problems experienced in implementing the semester English language curriculum. This sentiment was echoed by $\mathrm{T} 5$ as:

The voice of the stakeholders needs to be heard in the driving seat. Nobody asked for opinion, it is ok. But opinions should be taken after the implementation of the curriculum because teachers know what they need, what difficulties are there in implementation process, which course and content are useful and which are unnecessary. Curriculum evaluation needs to be regular.

The participants' responses affirm that the regular evaluation of implemented curriculum which plays a key role to meet the needs and demands of the people in one hand and to incorporate more voices in the curricular content. As 
Troudi and Alwan (2010) suggested that evaluation of the curriculum should be in ongoing basis and continuous and the results of which can be a key to modify the various components of the curriculum. To make effective and useful curriculum, teachers' voice, need analysis and respect to the continuous evaluation and its feedback are the hallmark.

\section{Conclusion and implications}

This study was designed to explore the teachers' insights into the effectiveness and usefulness of the current TU's Masters level English curriculum. Considering the complex nature of English language curriculum development and implementation process, a number of concerns in relation to context, input, and process were identified, and consequently, feedback and implications were drawn for future curriculum development and implementation process. It was reported that the input and curriculum were useful in terms of placing emphasis on practical issues and combining traditional and new pedagogical strategies. The teachers also reported that formative evaluation was a progressive step in the curriculum, however there was scepticism about its implementation. Conversely, designing and implementing curriculum without taking stakeholders input, without analysing their needs and the traditional context of teaching and learning were the negative aspects of the curriculum implementation. The study revealed that English language curriculum development and implementation overlooked a number of stages such as an analysis of the context and of what and how students learned, and how teachers taught them, and what materials and resources were available. Teachers were not trained and they were not given induction about the nature of curriculum and its implementation process. The teachers did not think that they were well informed, or consulted regarding the designing and implementing the current curriculum.

The gap between stakeholders and the curriculum designers and the centrally controlled formative evaluation became the obstacles in providing the quality teaching. Thus, the policy makers and curriculum designers should take into account the stakeholders' need, teacher training, teacher input and the context before they design curriculum.

Despite the fact that the study contributes to an understanding of the teachers' views into planning, preparing and implementing English curricula and curriculum studies in future, this study has a number of delimitations. First, it was a small-scale explanatory study incorporating only teachers' attitude in five aspects of curriculum, therefore, its findings may have limited applicability. A large scale incorporating multiple layers of participants such as policy makers, administrators, teachers, students and all other concerned stakeholders is needed to evaluate and determine the theoretical and practical claims of the curriculum. Nonetheless, it is hoped that this study raises awareness and provides feedback to the policy makers and curriculum designers on various aspects of the ELT curriculum design and implementation. 


\section{References}

Ahmadian, M., \& Rad, S. E. (2014). Postmethod era and globalized language curriculum development: A fresh Burden on language teachers. Journal of Language Teaching and Research, 5(3), 592-598.

Akbari, R. (2008). Postmodern discourse and practice. TESOL Quarterly, 42(4), 641-652.

Ali, M. M. (2016). Revisiting English language teaching curriculum design: How appropriate is Bangladesh higher secondary level national ELT curriculum as a learner centered one? IIUC STUDIES, 7, 283-296.

Bhattarai, K. P. (2014). Higher education in Nepal: Truth and challenges. IAESTE Nepal, 2.Retrieved from civilinitiative.org/254/.

Bista, M. (2016). Opinion of teachers towards semester system in mathematics education (unpublished M. Ed. thesis). Tribhuvan University, Kathmandu, Nepal.

Breen, M. P. (2001). Syllabus design. In R. Carter \& D. Nunan (Eds.). The cambridge guide to TESOL (pp. 151-159). Cambridge: Cambridge University Press.

Brown J. D. (1995). The elements of language curriculum. Boston: Heinle and Heinle Publishers.

Brown, H. D. (2007). Principles of language learning and teaching (5 ed.). White Plains, MY: Pearson Education.

Brown, M. (1989). Graded assessment and learning hierarchies in mathematics: An alternative view. British Educational Research Journal, 15(2), 121128.
Carl, A. (2005).The voice of teachers in curriculum development: A voice crying in the wilderness? South African Journal of Education,25 (4), 223-228.

Chongbang, K. B. (2014). Comparative study of semester system and annual system of faculty of education (mini research report). Faculty of Education, Tribhuvan University.

Cohen, L., Manion, L., \&Morrison, K. (2009). Research Methods in education( $4^{\text {th }}$ ed.). London: Routledge.

Egan, K. (2003). What is curriculum? Journal of the Canadian Association for Curriculum Studies 1(1), 9-16.

Faculty of Education (FOE) (n.d.). M. Ed. semester courses. Retrieved from tufoe.edu.np/curriculum/14.

Fashim, M., \& Pishghadam, R. (2009). Postmodernism and English language teaching. Iranian Journal of Applied Language Studies, 1(2), 27-54.

Johnson, K. R. (1989). The second language curriculum.Cambridge: Cambridge University Press.

Kelly, A. V. (2009). The curriculum: Theory and practice $\left(6^{\text {th }} \mathrm{ed}\right.$.). London: SAGE.

Kubeki, A. S. (2018). What is the importance of curriculum in education. Retrieved from https://www.quora.com/whatis-the-importance-of-curriculum-ineducation/profile/Alise-starkeykubeki.

Kumaravadivelu, B. (2001). Towards postmethod pedagogy. TESOL Quarterly, 35(4), 537-60. Retrieved from doi: $10.2307 \% 2 \mathrm{f} 3588427$. 
Kumaravadivelu, B. (2006). Understanding language teaching: From method to postmethod.New York: Routledge.

Mackey, A., \& Grass, S. M. (2005). Second language research: Methodology and design. NJ: Lawrence Erlbaum Associates.

Marope, M. (2017). Reconceptualizing and repositioning curriculum in the $21^{\text {st }}$ century: A global shift. International Bureau of Education. Retrieved from www.ibe.unesco.org/sites/default/ files/resources/reconceptualizingand-repositioning.pdf.

Mednick, F. (2006). Curriculum theories(Version 1.9). Retrieved from http:cnx.org/content/m13293/latest/

Nation, I. S. P. \& Macalister, J. (2010). Language curriculum design. London: Routledge.

Null, W. (2011). Curriculum: From theory to practice. London: Rowmar and Littlefield.

Nunan, D. (2010). Syllabus design. London: Oxford University Press.

O'Sullivan, M. (2004). The reconceptualization of learner centered approaches. A Namibian case study. International Journal of Educational Development, 24(6), 585602.

Paudyal, S. (2016). Higher education academic standard in Nepal(unpublished M. Phil thesis). University of Oslo, Canada.

Peacock, M. (2009). The evaluation of foreign-language teacher education programmes. Language Teaching Research,13(3),259-78.
Ramely, J. A. (2014 b). The changing role of higher education: Learning to deal with wicked problems. Journal of Higher Education Outreach and Engagement, 18(3), 7-22.

Richards, J. C. (2010). Curriculum development in language teaching. Cambridge: Cambridge University Press.

Richards, J. C., \& Rodgers, T. S. (2001). Approaches and methods in language teaching. Cambridge: Cambridge University Press.

Rodgers, T. S. (2010). The future of language teaching methodology. Retrieved from http:// www.journal.teflin.org/ index.php/teflin/article/viewfile/ $168 / 53$.

Scriven, M. (1972). Pros and cons about goal free evaluation. In W. J. Pophan (Ed.). Evaluation in education: Current applications (pp. 34-67). Berkely, CA: McCuthon.

Selingo, J. (2016). There is life after college: What parents and students should know about navigating school to prepare the jobs tomorrow. New York: William Morrow.

Simons, C. D. (2019, Feb 14). What is the importance of curriculum determinants? Retrieved from https:// www.quora.com/profile/ChristinaDuganich-simons.

Spelling Commission (2006). A test of leadership charting the future of U.S. higher education (a report). Washington DC: US Department of Education.

Stufflebeam, D. C. (2003). The CIPP model for evaluation. In D. L. Stufflebeam \& T. Kelliaghan (Eds.). The international 
handbook for educational evaluation (pp. 31-62). Boston: Kluwer Academic Publishers.

Terrel, S. R. (2012). Mixed methods research methodology. TQK, 17(1), 254-280. Retrieved from http://nsuworksnova.edu/tqr/vol17/iss1/14.

Troudi, S., \& Alwan, F. (2010). Teachers' feeling during curriculum change in the United Arab Emirates: Opening Pandora's box. Teacher Development, 14(1), 107-121.

Uwadiae, O. (2018, Oct 26). What is the importance of curriculum in education. Retrieved from https:// www.quora.com/profile/MousinWani.

Wiggins, G. P., \& McTighe, J. (2006). Understanding by design. Virginia: Ascal.
Worthen, B. R., Sanders, J. R., \& Fitzpatrick, J. L. (1998). Program evaluation: Alternative approaches and practical guidelines. White Plains, NY: Longman

Zhang, G., Zeller, N., Griffith, R., Metcalf, D., Williams, J., Shea, C., \& Misulis, K. (2011). Using the context, input, process and product evaluation model (CIPP) as a comprehensive framework to guide the planning, implementation and assessment of service-learning programs. Journal of Higher Education Outreach and Engagement, 15(4), 57-83. 


\section{Appendix A}

\section{Closed ended Questionnaire}

Sir/ Madam, please contribute responding honestly to the questions regarding your attitudes towards English language curriculum of M.Ed. semester system. You can use the remarks column if you want to give more information.

1. How do you perceive the context of ELT curriculum implemented at semester system in M. Ed.?

\begin{tabular}{|l|l|l|l|l|}
\hline Context indicators $\sqrt{ }$ & Agree & Disagree & Not sure & Remarks \\
\hline Need based & & & & \\
\hline Useful & & & & \\
\hline Context based & & & & \\
\hline Creates opportunities & & & & \\
\hline
\end{tabular}

2. What challenges do you find in the ELT curriculum?

\begin{tabular}{|l|l|l|l|l|l|l|}
\hline $\begin{array}{c}\text { Challenges } \\
\Rightarrow\end{array}$ & $\begin{array}{c}\text { Course } \\
\text { completion } \\
\text { (Length) }\end{array}$ & $\begin{array}{c}\text { Students' } \\
\text { poor } \\
\text { background }\end{array}$ & $\begin{array}{c}\text { Traditional } \\
\text { Classroom } \\
\text { setting }\end{array}$ & $\begin{array}{c}\text { Lack of } \\
\text { Students' } \\
\text { seriousness/ } \\
\text { Motivation }\end{array}$ & $\begin{array}{c}\text { Lack of } \\
\text { Training } \\
\text { to the } \\
\text { teachers }\end{array}$ & $\begin{array}{c}\text { Poor } \\
\text { adminis- } \\
\text { trative } \\
\text { Mechanism }\end{array}$ \\
\hline $\begin{array}{l}\text { No. } \Rightarrow \text { of } \\
\text { respondents }\end{array}$ & & & & & & \\
\hline Remarks & & & & & & \\
\hline
\end{tabular}




\section{UNELTA}

3. What is your attitude towards input of the curriculum?

\begin{tabular}{|l|l|l|l|l|l|}
\hline $\begin{array}{l}\text { Input } \\
\text { indicators }\end{array}$ & Suitable & $\begin{array}{c}\text { Complex and } \\
\text { repeated }\end{array}$ & $\begin{array}{c}\text { Need more } \\
\text { reading } \\
\text { materials }\end{array}$ & $\begin{array}{c}\text { Practicable/ } \\
\text { usable }\end{array}$ & Remarks \\
\hline Objectives & & & & & \\
\hline Contents & & & & & \\
\hline Resources & & & & & \\
\hline
\end{tabular}

4. How do you conceptualize the process of curriculum?

\begin{tabular}{|l|l|l|l|l|}
\hline \multicolumn{1}{|c|}{$\begin{array}{c}\text { Indicators of } \\
\text { Process }\end{array}$} & Satisfactory & Conditional & Not effective & Remarks \\
\hline $\begin{array}{l}\text { Instructional } \\
\text { Strategies }\end{array}$ & & & & \\
\hline Evaluation Process & & & & \\
\hline
\end{tabular}

5. How was your involvement in curriculum development/ design process?

\begin{tabular}{|l|l|l|l|l|}
\hline $\begin{array}{l}\text { Nature } \Rightarrow \text { of } \\
\text { Involvement }\end{array}$ & $\begin{array}{c}\text { Actively } \\
\text { Engaged }\end{array}$ & $\begin{array}{c}\text { Consulted but } \\
\text { not engaged }\end{array}$ & $\begin{array}{c}\text { Totally being } \\
\text { Ignored }\end{array}$ & Remarks \\
\hline $\begin{array}{l}\text { No } \Rightarrow \text { of } \\
\text { participants }\end{array}$ & & & & \\
\hline
\end{tabular}

6. List out the strengths and weakness of the curriculum and also give your recommendations.

\begin{tabular}{|l|l|l|}
\hline Strengths & Weaknesses & Recommendations \\
\hline & & \\
\hline & & \\
\hline & & \\
\hline & & \\
\hline
\end{tabular}




\section{Appendix B}

\section{Open ended Questionnaire}

Name: (optional):

Post:

Campus/college:

1. How long have you teaching English language to the students of Masters, in English education?

2. How have you been feeling on the shifting from annual to semester system?

3. Were you involved yourself in semester curriculum development process?

If yes, what types of criteria were set up for selecting the syllabi and other resources in the curriculum?

If no, did anyone ask your opinion as an experience professional regarding the courses and content to be incorporated in the semester programme?

4. What differences do you find in annual system curriculum and semester system curriculum? And which one do you find effective and easy to implementation?

5. How are you being prepared for the changes offered in the semester curriculum? Are you being given any training, course orientation or any other facilities for that?

6. How do you perceive the context (needs, goals \& situation), objectives, contents (Courses and their focused areas) and processes (both instructional \& evaluation) of the curriculum.

7. What challenges are you facing while implementing the semester curriculum?

8. How do you indicate the strengths and weaknesses in the semester curriculum?

9. What suggestion do you recommend for making the English curriculum effective, efficient, useful and contextual?

Contributor: Pitambar Paudel is a Lecturer of English Education at Tribhuvan University, Nepal. To his credit, about three dozens of articles have been published in different national and international journals. He has also published books, edited journals and presented papers in various ELT conferences. His areas of interest include applied linguistics, research methodology, translation studies, research on SLA and English Language curricula, Teacher professional development and ICT in language education. 